This is the author's final, peer-reviewed manuscript as accepted for publication. The publisher-formatted version may be available through the publisher's web site or your institution's library.

\title{
The invasive Lespedeza cuneata attracts more insect pollinators than native congeners in tallgrass prairie with variable impacts
}

Teresa M. Woods, Jayne L. Jonas, Carolyn J. Ferguson

\section{How to cite this manuscript}

If you make reference to this version of the manuscript, use the following information:

Woods, T. M., Jonas, J. L., \& Ferguson, C. J. (2012). The invasive Lespedeza cuneata attracts more insect pollinators than native congeners in tallgrass prairie with variable impacts. Retrieved from http://krex.ksu.edu

\section{Published Version Information}

Citation: Woods, T. M., Jonas, J. L., \& Ferguson, C. J. (2012). The invasive Lespedeza cuneata attracts more insect pollinators than native congeners in tallgrass prairie with variable impacts. Biological Invasions, 14(5), 1045-1059.

Copyright: (@ Springer Science+Business Media B.V. 2011

Digital Object Identifier (DOI): doi: 10.1007/s10530-011-0138-0

Publisher's Link: http://www.springerlink.com/content/q89807r1161215tu/

This item was retrieved from the K-State Research Exchange (K-REx), the institutional repository of Kansas State University. K-REx is available at http://krex.ksu.edu 


\title{
The invasive Lespedeza cuneata attracts more insect pollinators than native congeners in tallgrass prairie with variable impacts
}

\author{
Teresa M. Woods ${ }^{1}$, Jayne L. Jonas ${ }^{2}$, Carolyn J. Ferguson ${ }^{3}$ \\ ${ }^{1}$ Kansas State University, Olathe Campus, 22201 W. Innovation Drive, Olathe, KS \\ 66061
}

$785-532-9834$

twoods@ksu.edu

${ }^{2}$ Colorado State University, Department of Forestry, Rangeland, and Watershed Stewardship, Fort Collins, CO 80523

${ }^{3}$ Kansas State University, Herbarium and Division of Biology, Ackert Hall, Manhattan, KS 66506 


\section{Abstract}

Invasive plant species can potentially exert competitive or facilitative effects on insect pollination services of native species. Factors that influence these effects include the degree of shared pollinator species, synchronous flowering phenology, similar flower morphology and color, relatedness of invasive and natives, and showiness and densities of flowers. We investigated such plant-pollinator dynamics by comparing the invasive Lespedeza cuneata and three native congeners, all sympatric with synchronous flowering, using in situ populations over two years during peak floral displays. Insect visitation rates of the invasive were significantly higher per plant in both years than on the native species. The invasive exerted a competitive effect on visitation of two native species, and a facilitative effect on visitation of the native species with the highest degree of shared insect visitors. Positive correlations were found between floral density and visitation rate per plant in all the native species. Although no such correlation was found for the invasive, floral density in L. cuneata was at least twenty times higher than in the native species and likely saturated the pollinator community. Analyses of insect visitor taxonomic data indicated the insect communities visiting each of the Lespedeza species were generally similar though with speciesspecific differences. The main exception was that the common honeybee, Apis mellifera, was a primary visitor to the invasive plant species, yet was never observed on the native Lespedeza species.

\section{Keywords:}

Apis mellifera, Lespedeza, invasive, mixed mating system, pollination 


\section{Introduction}

Invasive species provide unique opportunities to investigate both ecological and evolutionary dynamics (Lambrinos 2004). Comparisons of invasive plant species with natives indicate that interactions vary from direct competition for resources (Barrat-Segretain 2005; Thomson 2005) to facilitative interactions (Richardson et al. 2000; Callaway et al. 2004; Bruno et al. 2005), with the most severe impacts of invasive plant species due to high relative abundance (D'Antonio and Hobbie 2005; Traveset and Richardson 2006). The introduction history and breeding systems of invasive species can also affect patterns of genetic structure in their adventive environments through dynamics of gene flow or isolation (Bossdorf et al. 2005; Dlugosch and Parker 2008), and rapid adaptation in some alien species has been documented (Lee 2002; Cox 2004; Prentis et al. 2008).

Understanding the reproductive systems of invasive species is fundamental to an improved understanding of their ecological and evolutionary dynamics. For instance, pollination can play a significant role in maintaining high propagule numbers, and high propagule pressure is often paramount to invasive plant success in establishment, maintenance of high relative abundance, and spread (Leung et al. 2004; Drake et al. 2005; Rejmánek et al. 2005). Lack of mutualist pollinators can limit the production of propagules in alien plants, as evidenced by several obligately outcross-pollinated Ficus species that only became invasive in Florida when their specialist pollinator wasp species were later introduced (McKey and Kaufmann 1988; Nadel et al. 1992). Rodger and colleagues additionally found that a plant invader, Lilium formosanum, that relies on a specialized pollinator can thrive in its adventive environment when that pollinator is naturally present (Rodger et al. 2010). While lack of pollinators can constrain the spread of alien species by limiting seed set (Parker 1997; Larson et al. 2002), most invasive plant species are not pollinated through such specialist relationships, but rather receive pollination service through generalist vectors to maintain high propagule pressure (Barthell et al. 2001; Brown et al. 2002; Parker and Haubensak 2002; Stout et al. 2006). Plants that rely on generalist pollinators are hypothesized to be more successful invaders since highly specialized plant species would be unlikely to encounter their pollinator species in a new 
environment (Baker 1974; Richardson et al. 2000; Rejmánek et al. 2005). Rather, plants with generalist pollinators can rely on multiple pollinator species with varying ranges, on alternative pollinators that may serve similar functional groups (Dalsgaard et al. 2008), or on generalist pollinators that have also been introduced into the same adventive environment (Simberloff and VonHolle 1999; Simberloff 2006; Abe et al. 2011).

Insect pollination of native plant species can be impacted by co-flowering invasive species, with dynamics ranging from competitive to null to facilitative, depending on context (Bjerknes et al. 2007; Muñoz and Cavieres 2008; Sargent and Ackerly 2008). Some invasive plants successfully compete with native species for pollinator services through more attractive floral rewards or simply due to greater floral display (Morales and Traveset 2009). For instance, the presence of Lythrum salicaria, invasive in North America, has been shown to reduce insect visits, pollination and seed set in the native congener L. alatum, which has a much smaller floral display than the invasive (Brown and Mitchell 2001; Brown et al. 2002). The invasive Impatiens glandulifera had a similar effect on several native co-occuring plant species in Germany due to its relatively higher quality of nectar (Chittka and Schürkens 2001). In Japan, the native Taraxacum japonicum was negatively affected through reduced insect visits and seed set in the presence of the invasive congener, T. officinale, which produces higher quality nectar despite its reliance on apomixis (Kandori et al. 2009; Takakura et al. 2009) Another mechanism implicated in reduced seed set of natives in the presence of invasives is the asymmetric deposition of heterospecific pollen on stigmas of native flowers (Brown and Mitchell 2001; Kandori et al. 2009).

Despite these studies, little evidence demonstrates that native plants actually suffer strict pollinator limitation due to the presence of invasives (Totland et al. 2006; Nielsen et al. 2008), and in some cases, alien plant species may actually support populations and networks of insect pollinators that service native species (Bjerknes et al. 2007; Valdovinos et al. 2009). In Mediterranean communities, for example, invasive Carpobrotus species were found to exert both competitive and facilitative species-specific effects on different native species (Moragues and 
Traveset 2005; Bartomeus et al. 2008). Contextual factors that influence the effects of alien plant species on pollination services to native plants include: the degree of dependence on pollinators, the degree of shared pollinator species, synchronous flowering phenology, similar flower morphology and color, relatedness of invasive and native species showiness and densities of flowers, amount of floral rewards, and population size and structure (Bjerknes et al. 2007; Muñoz and Cavieres 2008; Morales and Traveset 2009). These factors can work in concert, and can in fact be correlated; for instance, flower morphology is often similar in closely related plant species.

Shifts in pollinator visitation rates can affect the genetic diversity in native and invasive plant populations (Barrett et al. 2008; Wilson et al. 2009). Native populations can suffer reduced gene flow if pollinator service is reduced (Traveset and Richardson 2006). Invasive species can undergo local adaptation in their adventive environments through dynamics of gene flow and isolation (Barrett 1992; Allard et al. 1993; Levin 2003; Parker et al. 2003). A plant's mating system directly influences such patterns, with outcross-pollination conferring greater genetic variation upon which selection can act, and uniparental reproduction (selfpollination or asexual reproduction) facilitating more rapid genetic differentiation among populations as well as reproductive assurance (Allard et al. 1972; Novak et al. 1991; Daehler 1998; Pappert et al. 2000; Lambrinos 2001; Levin 2003; Barrett et al. 2008). Additionally, seeds formed from outcrossing are often more viable than those formed from selfing (Chang and Rausher 1998; Barrett 2003; Carr and Dudash 2003). Thus, pollination services can be important to an invasive species even with a mixed mating system.

The invasive Lespedeza cuneata (Dum. -Cours.) G. Don (Fabaceae) is an interesting case study where, via exclusion experiments, insect pollination has been shown to be important in seed set in a mixed mating system (Woods et al. 2009). Lespedeza species produce two types of flowers: showy chasmogamous flowers that can be pollinated by insects or by autonomous delayed-selfing (Woods 2006); and closed, inconspicuous, reduced cleistogamous flowers that are obligately self-pollinated. In a study comparing the invasive L. cuneata with three sympatric native congeners in tallgrass prairie, the invasive $L$. cuneata produced 
on average at least five times the number of seeds per plant than the native Lespedeza species (Woods et al. 2009). In the same study, the invasive L. cuneata also produced over twenty times the number of chasmogamous flowers (potentially insect-pollinated) than its sympatric native congeners, and was shown to benefit from insect pollination more than the co-flowering native Lespedeza species (Woods et al. 2009). While insect cross-pollination has been documented in most Lespedeza species (Stitt 1946; Donnelly 1955; Clewell 1964; Cope 1966), studies in the North American prairies have found evidence that native Lespedeza species may harbor less genetic variation among populations than the invasive $L$. cuneata (Cole and Biesboer 1992; Sundberg et al. 2002).

The general objective of this study was to assess plant-pollinator interactions of an invasive plant species in the context of its flexible breeding system. Our approach was to compare the plant-pollinator dynamics of the invasive Lespedeza cuneata with multiple congeneric native species in natural populations in the tallgrass prairie. Our general hypothesis was that the invasive L. cuneata would have more interactions with insect floral visitors than native congeners. Specific predictions were that, in natural populations: 1 ) the invasive $L$. cuneata would have a higher insect visitation rate than the native congeners; 2) size of floral display would correlate with insect visitation rate; and 3) the invasive L. cuneata would be more generalist-pollinated than the native species (that is, the taxonomic diversity of insects visiting would be greater than for the native congeners).

\section{Materials and methods}

\section{Study species}

Four species in the genus Lespedeza were studied: the non-native invasive $L$. cuneata; and three native species, L. capitata Michx., L. violacea (L.) Pers., and L. virginica (L.) Britton. All are perennial legumes that form natural populations in the North American tallgrass prairie of Kansas (Great Plains Flora Association 1986), and all occur sympatrically. Lespedeza cuneata is native to eastern Asia, and was introduced into eastern United States originally for erosion control. In tallgrass prairie, L. cuneata forms dense stands, rapidly displacing native grasses 
(Ohlenbusch et al. 2007). Voucher specimens of each species from each study site for this investigation have been deposited at the Kansas State University Herbarium (KSC).

All four species have seeds that require scarification for germination, with fire stimulating seedling emergence (Clewell 1966). They are also clonal, with vegetative buds on the stem base and woody rhizomes augmenting sexual reproduction. Each plant generally consists of multiple interconnected stems (hereafter referred to as ramets) that together comprise a separate and independent Integrated Physiological Unit (IPU) (Watson and Casper 1984), hereafter referred to simply as plant. Over time, some ramets become independent through senescence of the connecting rhizome. For the purposes of this study, ramets emerging from a common base were considered to constitute one plant.

The species produce flowers for approximately four weeks from late July to midSeptember, with all species overlapping in flowering phenology. Within this general timeframe, the four Lespedeza species studied demonstrate variable flowering patterns in varying environments (Woods et al. 2009). They produce single-seeded legumes that mature in 4-5 weeks, remaining potentially viable for over 50 years (Clewell 1966). The native species are known to hybridize among themselves, though hybridization of $L$. cuneata with the natives is precluded by differences in chromosome number: L. cuneata $n=19$; North American Lespedeza species $n=10$ (Clewell 1966).

The showy chasmagamous flowers typically open in the morning and last one day before wilting. These papilionaceous flowers are approximately $1 \mathrm{~cm}$ long with a standard, two wings and a keel, and the reproductive organs are contained within the keel. The greatly reduced, inconspicuous cleistogamous flowers are interspersed within the inflorescences and are obligately self-pollinating (Woods et al. 2009).

The corollas of $L$. cuneata and L. capitata are white to cream-colored, those of $L$. violacea and L. virginica are pink-purple, and flowers of all species have deep 
purple or magenta coloring at the base of the standard. The flowers of each species are borne on the stem in distinct patterns.
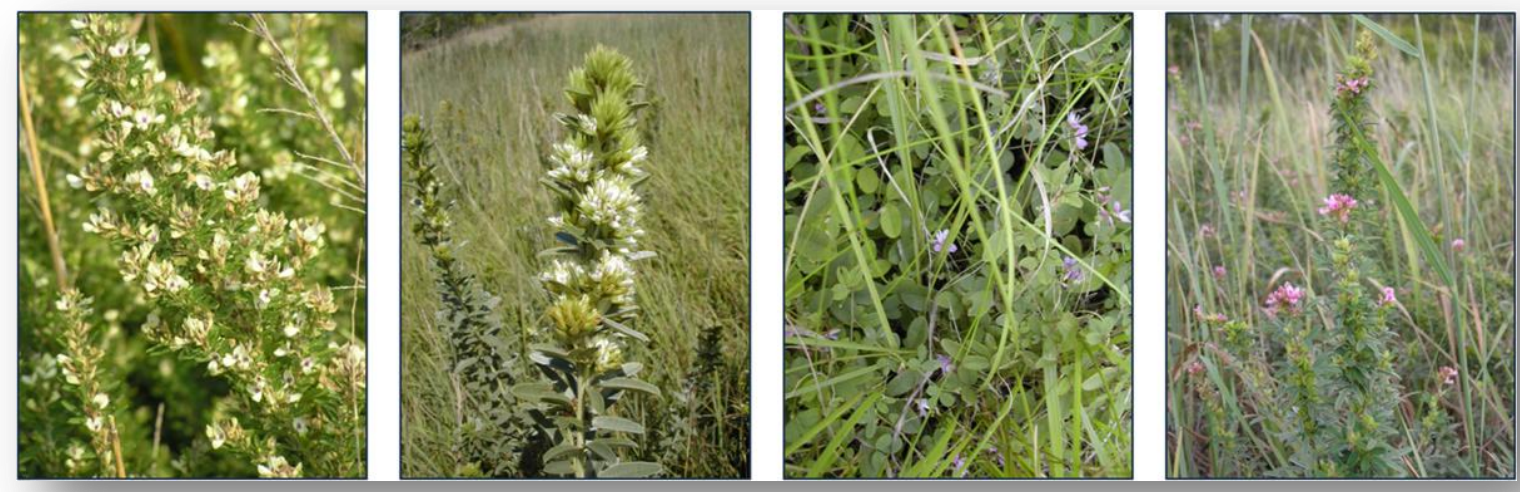

Fig. 1 Floral displays of the four study species, from left to right: L. cuneata (invasive); L. capitata (native); L. violacea (native); L. virginica (native).

Lespedeza cuneata bears flowers in many axillary racemes along most of the length of the stem; L. capitata forms a dense terminal capitate inflorescence, often with thyrsoid inflorescences at nodes; L. violacea bears flowers in loose and well separated axillary racemes along its relatively thin stems; and L. virginica bears a few flowers in tight axillary racemes along the mid to upper parts of its stem, often culminating in a loose terminal thyrsoid inflorescence.

Each flower contains ten diadelphus stamens and a single carpel with a style that grows through the fused stamens. The style elongates and bends the stigma upward and often out of the keel prior to elongation of the filaments, with trichomes forming a slight barrier between the stigma and anthers (Clewell 1966; Cope 1966). Despite this physical barrier, a certain degree of autonomous selfpollination in chasmogamous flowers has also been found to occur (Woods et al. 2009). Nonetheless, through insect exclusion experiments, Woods and colleagues (2009) found that the chasmogamous flowers of these four species are primarily insect-pollinated. Although these Lespedeza species produce self-pollinated seeds through autonomy in chasmogamous and cleistogamous flowers, the seeds produced by chasmogamous flowers, and especially through outcrossing, are known to have significantly higher viability rates than those produced by cleistogamous flowers (Donnelly 1955; Schutzenhofer 2007). 


\section{Study sites}

Six sites with wild populations of the Lespedeza species located in northeastern Kansas, USA, were utilized for this study. At least two sites per species of natural populations were utilized and replicated for two years.

Table 1 Field Sites: location (county, latitude, and longitude) and brief description of field sites sampled indicating which Lespedeza species and years were studied at each site in Kansas (USA).

\begin{tabular}{|c|c|c|c|c|c|c|}
\hline Site & $\begin{array}{l}\text { Latitude/Longitude } \\
\text { (County) }\end{array}$ & Description & $\begin{array}{c}L . \\
\text { cuneata }\end{array}$ & $\begin{array}{c}L . \\
\text { capitata }\end{array}$ & $\begin{array}{c}L . \\
\text { violacea }\end{array}$ & $\begin{array}{c}L . \\
\text { virginica }\end{array}$ \\
\hline (FR) Fort & $39^{\circ} 10^{\prime} \mathrm{N}, 96^{\circ} 41^{\prime} \mathrm{W}$ & old & 2004 & & & \\
\hline Riley & (Riley) & $\begin{array}{l}\text { agricultural } \\
\text { fields }\end{array}$ & 2005 & 2005 & & \\
\hline (K2A) Konza & $\begin{array}{l}39^{\circ} 06^{\prime} \mathrm{N}, 96^{\circ} 34^{\prime} \mathrm{W} \\
\text { (Riley) }\end{array}$ & $\begin{array}{l}\text { ungrazed } \\
\text { site at } \\
\text { KPBS* }^{*}\end{array}$ & & $\begin{array}{l}2004 \\
2005\end{array}$ & $\begin{array}{l}2004 \\
2005\end{array}$ & \\
\hline (WB) Konza & $\begin{array}{l}39^{\circ} 04^{\prime} \mathrm{N}, 96^{\circ} 34^{\prime} \mathrm{W} \\
\text { (Geary) }\end{array}$ & $\begin{array}{l}\text { ungrazed } \\
\text { site at } \\
\text { KPBS* }^{*}\end{array}$ & & $\begin{array}{l}2004 \\
2005\end{array}$ & $\begin{array}{l}2004 \\
2005\end{array}$ & \\
\hline $\begin{array}{l}\text { (P2) } \\
\text { Pottawatomie } \\
\text { No. } 2 \text { State } \\
\text { Lake }\end{array}$ & $\begin{array}{l}39^{\circ} 14^{\prime} \mathrm{N}, 96^{\circ} 31^{\prime} \mathrm{W} \\
\text { (Pottawatomie) }\end{array}$ & $\begin{array}{l}\text { prairie } \\
\text { surrounded } \\
\text { by mixed } \\
\text { woodland }\end{array}$ & 2004 & 2005 & $\begin{array}{l}2004 \\
2005\end{array}$ & \\
\hline $\begin{array}{l}\text { (PL2) Private } \\
\text { Land } 2\end{array}$ & $\begin{array}{l}39^{\circ} 21^{\prime} \mathrm{N}, 96^{\circ} 46^{\prime} \mathrm{W} \\
\text { (Riley) }\end{array}$ & $\begin{array}{l}\text { restored } \\
\text { grassland } \\
\text { surrounded } \\
\text { by farm fields }\end{array}$ & $\begin{array}{l}2004 \\
2005\end{array}$ & & & $\begin{array}{l}2004 \\
2005\end{array}$ \\
\hline (PL3A) & $39^{\circ} 16^{\prime} \mathrm{N} ; 96^{\circ} 28^{\prime} \mathrm{W}$ & open field & & & & 2004 \\
\hline $\begin{array}{l}\text { Private Land } \\
3 \mathrm{~A}\end{array}$ & (Pottawatomie) & $\begin{array}{l}\text { near riparian } \\
\text { woodland }\end{array}$ & & & 2005 & 2005 \\
\hline
\end{tabular}

Note: $*$ KPBS $=$ Konza Prairie Biological Station

Limitations to replication included lack of flowering in given sites and years (e.g., L. capitata at Fort Riley in 2004, L. violacea at PL3A in 2004), and eradication of 
the invasive species at Pottawatomie No. 2 State Lake in 2005. The region is characterized by a continental climate of warm, wet summers and dry, cold winters, and high levels of interannual variation in precipitation and temperature (Goodin et al. 2003). Lespedeza species were common but not dominant in terms of community composition. The Lespedeza species occurring sympatrically did so in estimated relative abundances that were similar, though it is worth noting that the greater number and size of ramets per plant of the invasive $L$. cuneata relative to its native congeners renders its spatial cover and vegetative density, including floral density, greater.

\section{Field Methods}

To assess insect visitation, twenty-minute observations of the four Lespedeza species were made at regular intervals, with each observation period comprising one sample. One to five plants with open flowers occurring in one-meter radius circles were observed during the midpoint of seasonal peak flowering time, and between the hours of 1100 and 1700 (the time period found in a 2003 pilot study to include the majority of the insect visitation activity for the plant species). The one-meter radius circles were randomly chosen by marking a $25 \mathrm{~m}$ transect through the middle of the population, selecting 12 potential sampling points at two meter intervals, and finding the nearest individual of the target plant species in a lateral direction. Transects were at least $30 \mathrm{~m}$ from prairie edge in all instances except the following: 1) Pottawatomie No. 2 State Lake, in which some samples were within $5 \mathrm{~m}$ of water's edge surrounded by prairie; and 2) Private Land $3 \mathrm{~A}$, in which some samples were within $5 \mathrm{~m}$ of riparian woodland surrounded by prairie. Each successive observation period was conducted on independent plants at least ten meters away, and individual plants were not resampled. When more than one species in the same site was observed, it was done when the invasive L. cuneata in the given site was flowering concurrently. Observation periods for different species growing in the same site were interspersed in time. Each site was monitored for two days. Weather conditions and limited flowering of native species limited sample size in some instances. 
An insect visit was recorded if an insect contacted the reproductive organs or the keel of an individual flower. A new insect visit was counted each time an insect visited a new flower. Vouchers of insect visitors were collected and were identified by Department of Entomology personnel at Kansas State University, generally to the genus level. Specimens are housed in the Kansas State University Herbarium (KSC).

The number of flowers per ramet was sampled by species and site each day. The number of aboveground ramets per plant (IPU) was also recorded to estimate plant size. More than one plant was frequently observed within the same time period (see Potts 2005). Thus, to account for overall floral density, the number of open conspecific flowers within a five-meter radius of each species under observation was also recorded for each observation period.

\section{Analysis}

Insect visitation rates were compared among species for the separate years 2004 and 2005. Visitation rate (VR) was calculated in two ways: (1) the rate per flower $\left[\mathrm{VR}_{\mathrm{flr}}=(\right.$ no. insect visits $) /($ flower $\times$ minute $\left.)\right]$; and (2) the rate per plant $\left[\mathrm{VR}_{\text {plnt }}=\right.$ (no. insect visits / (flower $\times$ minute $)) \times($ mean no. flowers / plant $)]$. The $\mathrm{VR}_{\mathrm{flr}}$ was calculated directly from observed insect observation periods. $\mathrm{VR}_{\text {plnt }}$ was calculated using the $\mathrm{VR}_{\mathrm{flr}}$ and the calculated daily number of flowers per plant from the same plant species, sites and years (Woods et al. 2009). The VR $\mathrm{R}_{\text {plnt }}$ was calculated due to its greater relevance for community questions (Potts 2005) and to enable consideration of population level issues associated with invasion. Visitation rates $\left(\mathrm{VR}_{\mathrm{flr}}\right.$ and $\left.\mathrm{VR}_{\mathrm{plnt}}\right)$ were compared by conducting tests for differences among species using a mixed model restricted maximum likelihood (REML) analysis, allowing for unequal variances within species, and conducting pairwise comparisons using differences in least-squares means (SAS Institute Inc. 2002-2003).

The Wilcoxon rank-sum exact test (SAS Institute Inc. 2002-2003) was used to examine the impact of the presence of the invasive $L$. cuneata on visitation rates for the natives L. capitata (2005 only), L. violacea (2004), and L. virginica (2004 
and 2005) by comparing $\mathrm{VR}_{\mathrm{flr}}$ and $\mathrm{VR}_{\mathrm{plnt}}$ at sites where the native species occurred with $L$. cuneata versus without $L$. cuneata. In 2004, flowering plants of L. capitata and L. cuneata did not co-occur at any sites sampled. In $2005 \mathrm{~L}$. violacea failed to flower. Due to small sample sizes, skewed distributions and wide ranges of observations in the datasets for the native species, the nonparametric test was deemed the most appropriate approach to assessing the effect of the invasive species on pollinator visitation rates of the natives.

To test for a relationship between insect visitation rate and floral density, $\mathrm{VR}_{\mathrm{plnt}}$ was plotted against the number of conspecific flowers within a five-meter radius of the flowers under observation (floral density) using a simple linear regression. Data were pooled for 2004 and 2005 within plant species and transformed to achieve normality, with the inverse of $\mathrm{VR}_{\mathrm{plnt}}\left(\mathrm{VR}_{\mathrm{plnt}}{ }^{-1}\right.$ ) plotted against log (floral density). For ease of interpretation, values were back-transformed to the original scale for presentation and discussion of relationships.

To compare diversity of insect visitors, rarefaction curves were developed using EstimateS software (Colwell 2005). Rarefaction curves allow comparison of different communities, in this case insect visitors to different plant species, given different sample sizes. A sample was considered a single observation period. Mau's tao calculations were used, with 100 randomized runs with replacement. The similarity of insect taxa visiting each plant species was compared. For purposes of analysis, insect visitors on each plant species were considered one insect community, and insect taxonomic groups identified at the finest level (either species or genus as described above) were considered a single species for purposes of analysis. For each year, the following were calculated: the number of insect taxa observed on each plant species, the number of shared insect taxa observed, and the Morisita-Horn community similarity index (Colwell 2005).

Insect visitor community composition was assessed for each plant species in each year by determining the percentage of visits attributed to each insect order. Because the majority of insect visitors were hymenopterans, the percentages of visits within this order were further determined to the family level. 


\section{Results}

A total of 98 insect visitation observation periods (samples) were conducted over two years: 38 in 2004; and 60 in 2005. Insect visitation rates among the plant species differed significantly when calculated on the basis of both flower $\left(\mathrm{VR}_{\mathrm{flr}}\right)$ and plant $\left(\mathrm{VR}_{\mathrm{plnt}}\right)$ in $2004\left(F_{3,34}=3.55, P=0.245\right.$; and $F_{3,22.8}=8.16, P=0.0007$; respectively), but only in $\mathrm{VR}_{\text {plnt }}$ in $2005\left(F_{2,5.73}=6.68, P=0.0318\right)$.
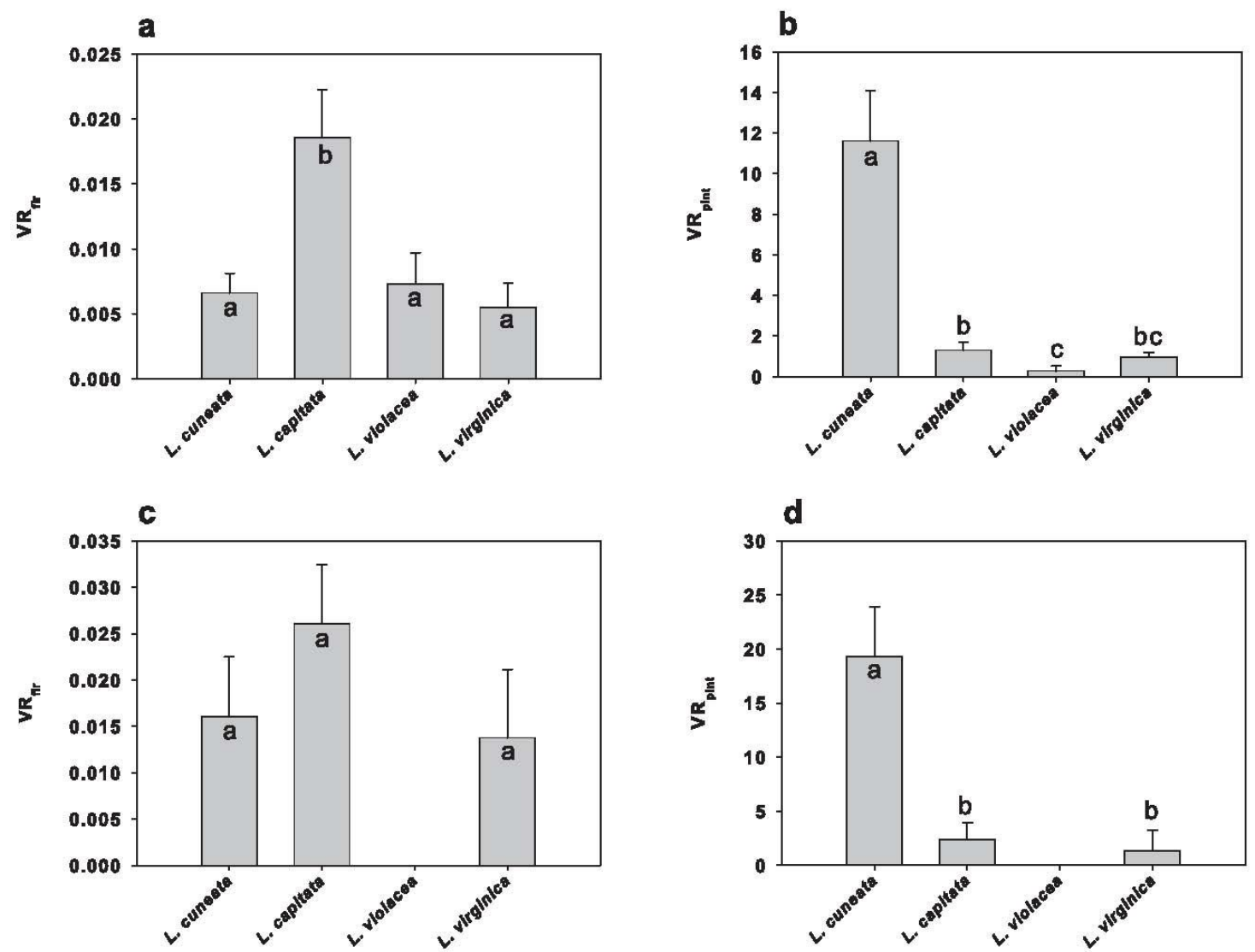

Fig. 2 Insect visitation rates among Lespedeza species: (a) visitation rates per flower $\left(\mathrm{VR}_{\mathrm{flr}}\right)$ in 2004; (b) visitation rates per plant $\left(\mathrm{VR}_{\mathrm{plnt}}\right)$ in 2004; (c) visitation rates per flower $\left(\mathrm{VR}_{\mathrm{fll}}\right)$ in 2005 ; and $(\mathbf{d})$ visitation rates per plant $\left(\mathrm{VR}_{\mathrm{plnt}}\right)$ in 2005 . Each sample represents one observation period monitoring numerous ramets on up to five plants. In 2004, $\mathrm{n}=17$ for $L$. cuneata, $\mathrm{n}=3$ for $L$. capitata, $\mathrm{n}=7$ for $L$. violacea, and $\mathrm{n}=11$ for $L$. Virginica. In $2005, \mathrm{n}=18$ for $L$. cuneata, $\mathrm{n}=22$ for $L$. capitata, and $\mathrm{n}=19$ for $L$. virginica. Note the lack of data due to no flowering in L. violacea in 2005. Different letters indicate significant differences between species $(P$-value $<0.05)$.

In both years the native $L$. capitata had the highest $\mathrm{VR}_{\mathrm{flr}}$, and the invasive $L$. cuneata had the highest $\mathrm{VR}_{\text {plnt }}$. In 2004 , the mean $\mathrm{VR}_{\text {plnt }}$ for L. cuneata was nearly ten times that of any other native Lespedeza studied, and in 2005 the mean $\mathrm{VR}_{\text {plnt }}$ for $L$. cuneata was over eight times those of the native congeners. The 
differences between $\mathrm{VR}_{\text {flr }}$ and $\mathrm{VR}_{\text {plnt }}$ are related to the prolific number of flowers per stem and stems per plant in L. cuneata relative to the other species (Woods et al. 2009). Sampling was somewhat uneven due to the uneven chasmogamous flowering between seasons and sites among the species. For instance, L. violacea had low flowering in 2004, and failed to flower in 2005 (for more details, see Woods et al. 2009). Sites continued to be monitored even when flowering did not occur.

Comparisons of visitation rates for native Lespedeza species with and without $L$. cuneata as a sympatric species yielded variable results. The presence of $L$. cuneata had a marginally negative impact on $\mathrm{VR}_{\mathrm{flr}}$ of $L$. capitata in 2005 ( $S=25.0$, $P=0.0781)$ as well as on $L$. violacea in $2004(S=6.0, P=0.0571)$, and it had no effect on L. virginica in either 2004 ( $S=25.0, P=0.8848)$ or 2005 ( $S=64.5$, $P=0.7170$ ) (Fig.3a). However, analysis of the more ecologically relevant $\mathrm{VR}_{\text {plnt }}$ showed that in the presence of $L$. cuneata, insect visitation rates were significantly lower for $L$. capitata in 2005 ( $S=14.0, P=0.0031)$, marginally lower for $L$. violacea in 2004 ( $S=6.0, P=0.0571)$, unaffected for $L$. virginica in 2004 ( $S=27.0$, $P=0.6182)$, but significantly greater for $L$. virginica in $2005(S=85.5, P=0.0227)$ (Fig.3b). 

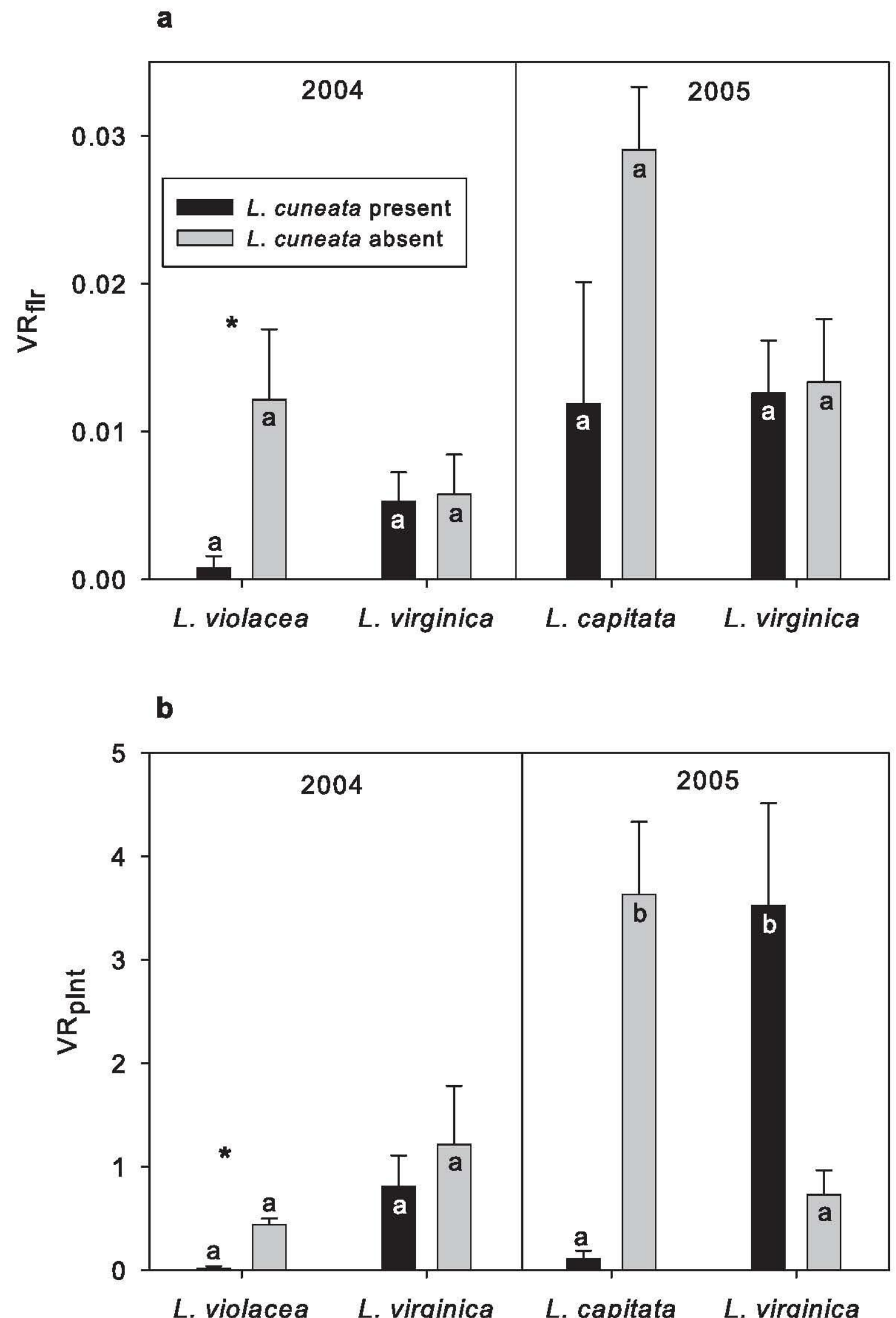

Fig. 3 a and $\mathbf{b}$ Insect visitation rates for the native species Lespedeza capitata, $L$. violacea and $L$. virginica as influenced by the presence or absence of the invasive $L$. cuneata: (a) visitation rates per flower $\left(\mathrm{VR}_{\mathrm{flr}}\right)$; (b) visitation rates per plant $\left(\mathrm{VR}_{\mathrm{plnt}}\right)$. Data 
were analyzed separately for each species $\mathrm{x}$ year; data to make these comparisons were only available for $L$. capitata from 2005 ( $\mathrm{n}=4$ with and $\mathrm{n}=18$ without $L$. cuneata), for $L$. violacea from $2004(\mathrm{n}=3$ with and $\mathrm{n}=4$ without $L$. cuneata), and $L$. virginica from 2004 ( $\mathrm{n}=7$ with and $\mathrm{n}=4$ without $L$. cuneata) and 2005 ( $\mathrm{n}=6$ with and $\mathrm{n}=13$ without $L$. cuneata). Different letters indicate significant differences $(P$-value $<0.05), *$ indicates marginally significant differences $(0.05<P$-value $<0.06)$.

In assessing the relationship between visitation rates and floral density among the plant species, a significant correlation was found between $\mathrm{VR}_{\text {plnt }}{ }^{-1}$ and $\log$ (floral density) in all native species, where no significant correlation was found in the invasive L. cuneata. In terms of back-transformed relationships, greater floral density was associated with greater insect visitation rates for all native species. The linear equations, $r^{2}$-values, and $P$-values for these species are reported in Figure 4.
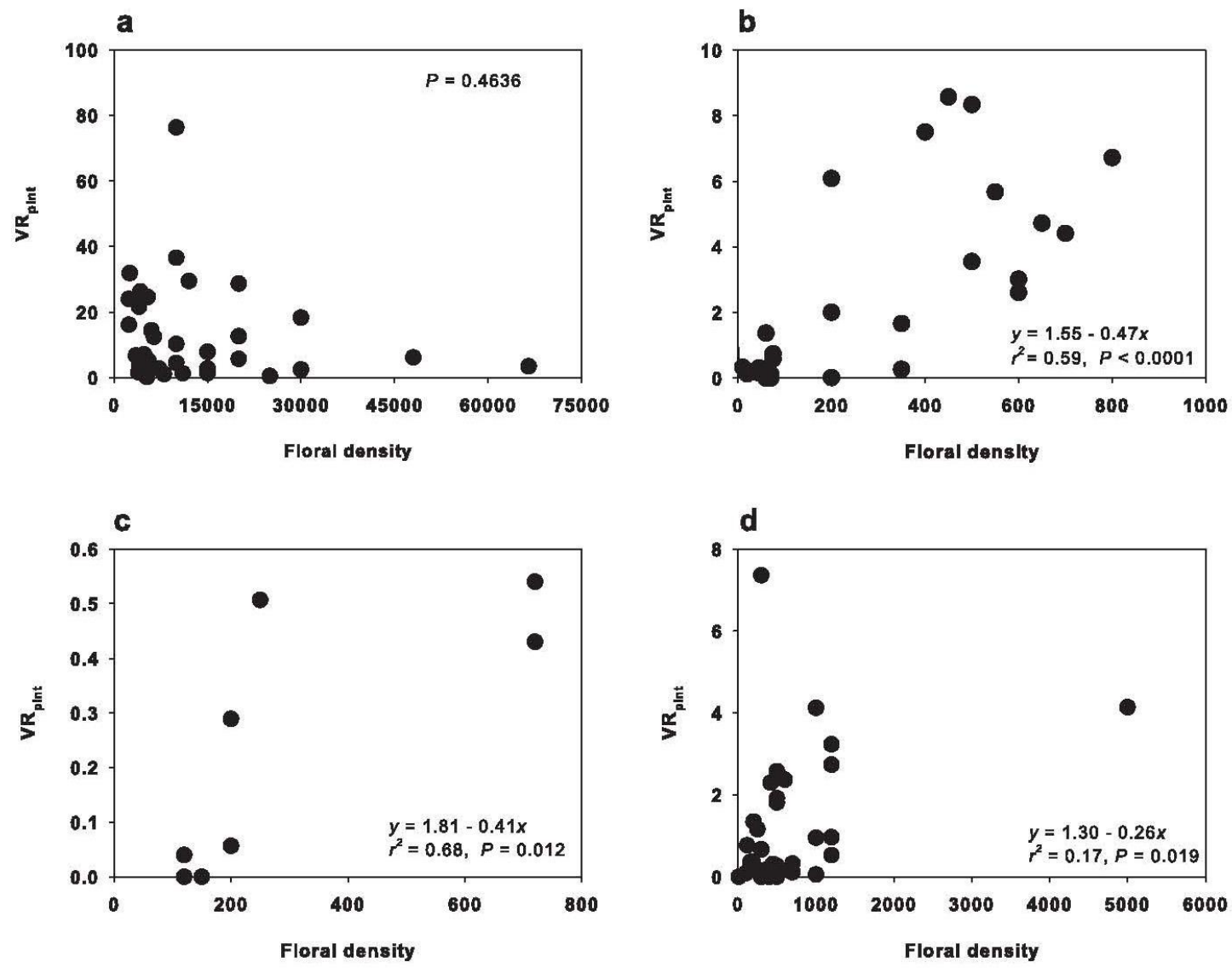

Fig. 4 Correlation of insect visitation rates per plant $\left(\mathrm{VR}_{\text {plnt }}\right)$ to floral density: (a) $L$. cuneata (invasive); (b) L. capitata (native); (c) L. violacea (native); and (d) L. virginica (native). Linear equations and regression coefficients $\left(r^{2}\right)$ are provided for significant least squares regressions where $y=\mathrm{VR}_{\mathrm{plnt}}{ }^{-1}$ and $x=\log ($ floral density +1$)$. Plotted values were back-transformed to the original scale for ease of interpretation. 
The rarefaction curve analysis demonstrated that while there was a higher species richness of insect visitors to L. cuneata than to the native species in both years, the difference was not significant (using a 95\% confidence interval), except relative to L. violacea in 2004.
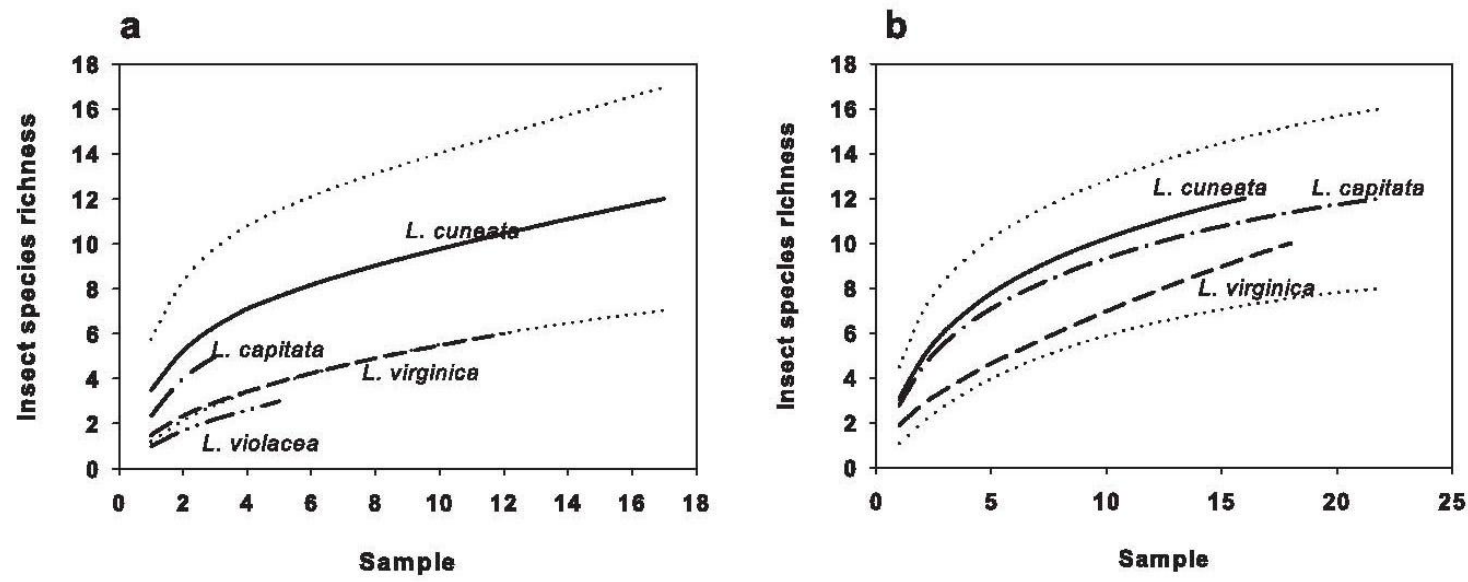

Fig. 5 Insect visitor diversity for different plant species during (a) 2004, and (b) 2005 . Insect diversity was based on insect visitors to each plant species, and one sample was considered one observation period. Different sample sizes were due to variable flowering in years and sites among species (there were no samples for L. violacea in 2005 as it failed to flower in all sites). Dotted lines indicate $95 \%$ confidence interval (CI) of the species with the widest CI (L. cuneata in 2004 and L. capitata in 2005). The solid line represents $L$. cuneata (invasive); dashed and single dotted line represents $L$. capitata; dashed line represents $L$. virginica; dashed and double dotted line represents $L$. violacea. Analysis based on EstimateS (Colwell 2005).

Sampling was greater in 2005, though the trends remained the same with $L$. capitata and L. virginica showing less insect visitor species richness, respectively, than the invasive L. cuneata (L. violacea was not sampled in 2005 due to lack of flowering that year). Pairwise comparisons for each year of the visiting insect communities to each plant species resulted in Morisita-Horn similarity indices between 0.670 and 0.863 (Tables 2 and 3), indicating that a majority of the visiting insect taxa visited more than one of these plant species. 
Table 2 Morisita-Horn community similarity index of insect visitors among Lespedeza species in 2004.

\begin{tabular}{|l|l|c|c|c|c|}
\hline Plant species 1 & Plant species 2 & Sobs1 & Sobs2 $_{\text {ond }}$ & Shared Sobs1-2 & Morisita-Horn \\
\hline L. cuneata & L. capitata & 14 & 6 & 2 & 0.670 \\
L. cuneata & L. violacea & 14 & 4 & 3 & 0.725 \\
L. cuneata & L. virginica & 14 & 8 & 6 & 0.743 \\
L. capitata & L. violacea & 6 & 4 & 1 & 0.707 \\
L. capitata & L. virginica & 6 & 8 & 1 & 0.696 \\
L. violacea & L. virginica & 4 & 8 & 3 & 0.863 \\
\hline
\end{tabular}

Note: $\mathrm{S}=$ the number of insect taxa observed visiting each plant species; Shared $\mathrm{S}$ $=$ shared insect taxa observed visiting both plant species.

Table 3 Morisita-Horn community similarity index of insect visitors among Lespedeza species 2005.

\begin{tabular}{|c|c|c|c|c|c|}
\hline Plant species 1 & Plant species 2 & S obs1 & Sobs2 $_{\text {of }}$ & Shared Sobs1-2 & Morisita-Horn \\
\hline L. cuneata & L. capitata & 13 & 17 & 8 & 0.780 \\
L. cuneata & L. virginica & 13 & 12 & 10 & 0.797 \\
L. capitata & L. virginica & 17 & 12 & 8 & 0.852 \\
\hline
\end{tabular}

Note: $\mathrm{S}=$ the number of insect taxa observed visiting each plant species; Shared $\mathrm{S}=$ shared insect taxa observed visiting both plant species.

The Morisita-Horn comparisons indicated that L. cuneata was visited by more insect taxa than the native species except in relation to L. capitata in 2005 (Table 3). The discrepancy between these comparisons and those shown by the rarefaction curves is due to the latter analysis accounting for uneven sampling sizes. 
a

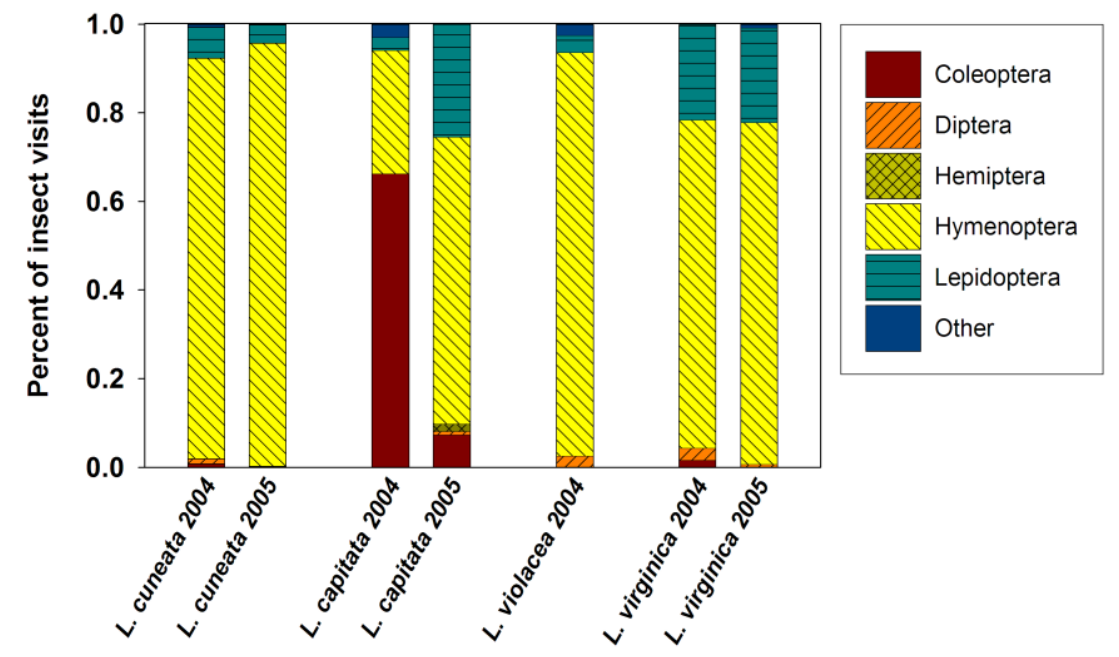

b

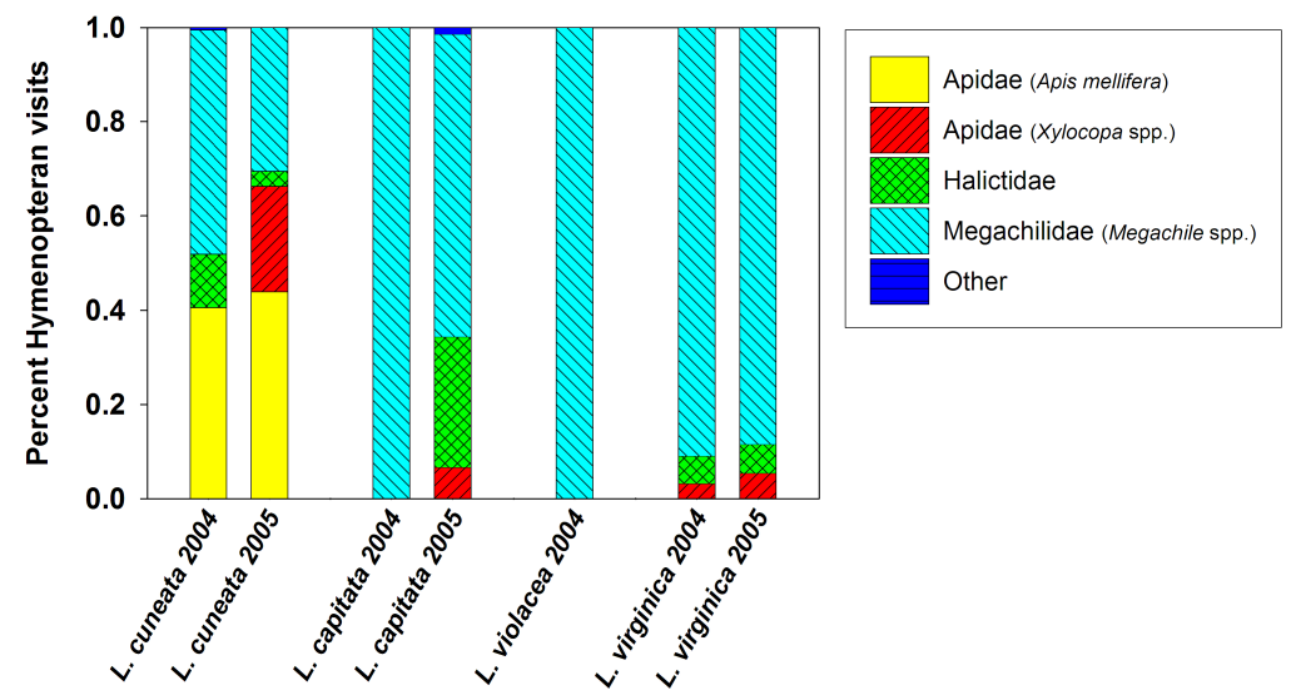

Fig. 6 Insect visitor taxonomic composition. For each plant species in each year, insect visitor taxa are represented on the vertical bar in the proportion they contributed to total visitation. (a) Differentiated bars represent different insect orders. Hymenopterans comprised the majority of visits in each instance, except for L. capitata in 2004. (b) Each bar represents total Hymenopteran visits, with differentiations representing different taxa. When major family visitors consisted of a single genus or species, it is indicated in the legend. The non-native bee, Apis mellifera, was a primary visitor to the invasive $L$. cuneata, yet was never observed on the native Lespedeza species.

The taxonomic breakdown of insects visiting each plant species shows that hymenopterans were the primary visitors in all cases except to L. capitata in 2004, in which case coleopterans were the most frequent visitors. Analysis of Hymenoptera visitors revealed that the primary visitor to all the native plants was the genus Megachile. In 2004, the primary insect visitors to L. cuneata were 
nearly evenly split between Megachile spp. and Apis mellifera, the common honeybee, while in 2005 , the primary visitor to L. cuneata was A. mellifera.

\section{Discussion}

Our study examined the plant-pollinator interactions in natural populations of an important invasive plant species, $L$. cuneata, in relation to three native congeners, all of which utilize multiple reproductive modes and a mixed mating system. The invasive Lespedeza species demonstrated a far greater insect visitation rate per plant than its native congeners, and impacted the visitation rates of native species in competitive, null and facilitative ways that varied by species and year. Insect visitation rates correlated with floral density in the native species, while the extreme floral density of the invasive likely saturated the pollinator community. The insect communities visiting each of the Lespedeza species were generally similar, with the exception that A. mellifera was a primary visitor to the invasive species, but was never observed on the native Lespedeza species.

Previous studies show that factors affecting the impacts of invasive plant species on the pollination dynamics of native plant species include: showiness and densities of flowers, degree of dependence on pollinators, degree of shared pollinators, synchronous flowering phenology, similar flower morphology and color and relatedness of invasive and native species (Bjerknes et al. 2007; Muñoz and Cavieres 2008; Mitchell et al. 2009; Morales and Traveset 2009).

The four Lespedeza congeners studied here share similar flower morphology, size and deep purple coloring at the base of the standard. All four species overlap in peak flowering phenologies and grow sympatrically in tallgrass prairie. Woods and colleagues (2009) established through insect exclusion experiments that insect pollination was important in chasmogamous seed production to all species. Furthermore, chasmogamously produced seeds have been shown to have higher viability rates than those produced by cleistogamous flowers (Donnelly 1955; Schutzenhofer 2007). 
Lespedeza cuneata had an insect visitation rate eight to ten times greater per plant than the native Lespedeza species. On a per flower basis, though, the invasive had a similar or lower mean insect visitation rate relative to the native species. This indicates that the higher visitation rate per plant of the invasive is due to its relatively high floral display and density in relation to the native Lespedeza species. While the actual relative abundance of each of the four Lespedeza species was similar in these natural populations, the invasive L. cuneata has a significantly greater number of ramets per plant and greater numbers of flowers per ramet, resulting in a floral display that averages at least twenty times those of the three native Lespedeza species (Woods et al. 2009).

Muñoz and Cavieres (2008) report that competitive effects for pollinators among native and invasive plant species primarily occur at high densities of the invasive relative to the natives. The positive correlation found in this study between floral density and insect visitation in the native Lespedeza species with no such correlation in the invasive $L$. cuneata suggests that the native plants would likely garner more insect visitors with greater floral density, but that the invasive $L$. cuneata exceeded the floral density required to attract more insects. Although the floral display of L. cuneata was more than $95 \%$ greater than those of the native species, competition for pollinators was only indicated for $L$. capitata and $L$. violacea, while $L$. cuneata seemed to facilitate pollinator visitation in $L$. virginica. Based on these in situ findings, controlled experimental tests on the native plants with and without the presence of the invasive are warranted to further elucidate the competitive and facilitative effects that $L$. cuneata exerts on insect pollination in co-occurring native Lespedeza species.

Lespedeza cuneata and the native species were shown to generally, though not completely, share a similar insect pollinator community in these tallgrass prairie sites. While L. cuneata was visited by a greater number of insect taxa, the difference was not significant. Interestingly, the largest number of shared insect taxa (63\%) existed between the invasive L. cuneata and the native L. virginica. Lespedeza virginica is also the native species registering a facilitative effect from insect visitors to the invasive. The overall plant architecture of these two species is similar, even though their flowers are different colors (cream colored, and pink, 
respectively). Conversely, in 2005 the native L. capitata shared only $21 \%$ of visitor taxa with $L$. cuneata and also had lower $\mathrm{VR}_{\text {plnt }}$ when growing sympatrically with L. cuneata. These results suggest that the presence of the invasive $L$. cuneata may exert a facilitative effect on visitation rates of native species when they share similar pollinator communities.

The most prominent insect visitor overall was the genus Megachile, and the bodies of these bees are particularly well-suited to pollination of these Lespedeza flowers. As the bees land on the keel and forage at the nectaries, they tend to work the keel open with their legs, exposing the anthers which deposit pollen directly onto the abdomen of the bees. On more than one occasion, Megachile were directly observed moving between the L. capitata and L. violacea. These two native plant species often hybridize to form Lespedeza x manniana Mack. \& Bush (pro sp.), and hybrid individuals were documented at those sites (Woods 2006).

The prominence of the insect Apis mellifera as a visitor to the invasive L. cuneata, when it was never recorded on any of the native Lespedeza species, is an important finding in this study. Apis mellifera is native to Eurasia and Africa, and has been introduced to most of the rest of the world, including North America. The honeybee has facilitated the invasion of numerous alien plant species through its pollination service (Barthell et al. 2001; Parker and Haubensak 2002; Stout et al. 2002). While it is unlikely that L. cuneata is as dependent on A. mellifera pollination as some other invasive plants, these findings suggest it may be affecting pollinator networks, such as shifts in native bee foraging. Schaffer and colleagues $(1979 ; 1983)$ found changes in patterns of niche-partitioning among bee communities in the presence of $A$. mellifera, with native bees shifting to less productive foraging sites and flower species, while the introduced honeybees preferentially foraged at the most productive floral resources. Gross (2001) also found a negative correlation between native bee presence and introduced honeybee presence on an endemic shrub in Australia, with the honeybee ranking as the primary pollinator. Studies examining pollinator networks with and without the presence of $L$. cuneata could elucidate the influence that both the 
invasive plant, and its facilitation of Apis mellifera populations, have on native species.

The high insect visitation rate per plant found for the invasive L. cuneata (eight to ten times that of any of the three native Lespedeza species) may be most important in terms of the maintenance of genetic variation within populations relative to the native species. Other studies on Lespedeza species in North American prairies indicate interesting patterns of genetic diversity. Cole and Biesboer (1992) found low levels of heterozygosity in the widespread native L. capitata, yet strong genetic differentiation among populations. This is consistent with high levels of self-pollination. Cole and Biesboer (1992) contrasted populations of L capitata with populations of the native L. leptostachya Engelm., which is threatenened and endangered, finding that the former maintained far greater genetic variation and gene flow than existed in the latter, suggesting that even a low level of outcrossing is important in maintaining viable populations. In contrast, Sundberg and colleagues (2002) found considerable genetic variability in invasive $L$. cuneata plants selected from different populations. This may be due to relatively greater outcrossing levels that maintain greater genetic diversity within and among populations, or due to a history of multiple introductions of L. cuneata, or both. Cope (1966) found outcrossing levels in L. cuneata between $16 \%$ and $43 \%$ of seed set by chasmogamy.

Lespedeza species have complex reproductive systems, enabling them to produce local propagules vegetatively as well as sexually. More specifically, they reproduce through rhizomatous buds, and through seeds produced through both selfing and outcrossing. This suite of reproductive modes can be advantageous in various and varying conditions, contributing not only to high propagule production but also to reproductive fitness homeostasis in the invasive (Barrett et al. 2008; Woods et al. 2009). Propagules produced asexually or through selfpollination can be advantageous in establishing new populations where mates or pollinators may be absent, while clonal reproduction can ensure persistence and increasing density over time by enlarging existing clones (Brock et al. 1995; Pyšek et al. 2001). The density created by vegetative budding is a dominant strategy of L. cuneata in shading neighboring plants (Brandon et al. 2004), and is 
also implicated in formation of its relatively dense and showy floral display (Woods et al. 2009). In contrast, plants that reproduce only through outcross pollination confer greater standing genetic diversity, providing an advantage in the potential for adaptive evolution (Lambrinos 2001; Dlugosch and Parker 2008). Most models of the reproductive biology of invasive or colonizing plant species predict selective advantages for mixed mating systems that balance reproductive assurance through self-pollination or asexual reproduction, with the benefits of genetic variation through outcross-pollination (Lloyd 1992; Pannell and Barrett 1998; Barrett et al. 2008).

Such selective advantages of the mixed mating system of native North American Lespedeza species have been highlighted by Clewell (1964; 1966). Additionally, the findings of higher genetic diversity among invasive L. cuneata populations in relation to native Lespedeza populations (Cole and Biesboer 1992; Sundberg et al. 2002) are consistent with our finding that the invasive L. cuneata maintains an insect visitation rate eight to ten times that of the native Lespedeza species. This higher insect visitation rate suggests a higher degree of gene flow through pollination than its native congeners. Future studies comparing the genetic diversity among the invasive and native Lespedeza species would be fruitful, and exploration of whether L. cuneata demonstrates evidence of clinal or local adaptation could shed light on the role of its flexible reproductive system and mixed mating system in its successful spread.

\section{Acknowledgments:}

The authors thank David C. Hartnett and Anthony Joern for invaluable guidance, and for comments on an earlier version of this manuscript. We also are grateful for the expert contributions of Robert Brown, Greg Zolnerowich, and Mark Mayfield, as well as the field assistance of Ruth Gibson and Sarah Haller. The land managers and landowners of our sites were generous and gracious, and we are indebted to them: Jerold Spohn at Ft. Riley Military Base; James Hulbert at Pottawatomie No. 2 State Lake; Tom Van Slyke and Jim Larkins at Konza Prairie Biological Station; Dru and Mike Clarke; and Jerry Hageman. We acknowledge support from the Konza Prairie Biological Station. This is contribution number 11-335-J of the Kansas Agricultural Experiment Station. 


\section{References}

Abe T, Wada K, Kato Y, Makino S, Okochi I (2011) Alien pollinator promotes invasive mutualism in an insular pollination system. Biol Invasions 13:957-967

Allard RW, Babbel GR, Clegg MT, Kahler AL (1972) Evidence for coadaptation in Avena barbata. Proc Natl Acad of Sci 69:3043-3048

Allard RW, García P, Sáenz-de-Miera LE, Vega MPdl (1993) Evolution of multilocus genetic structure in Avena hirtula and Avena barbata. Genet 135:1125-1139

Baker HG (1974) The evolution of weeds. Annu Rev Ecol Syst 5:1-24

Barrat-Segretain MH (2005) Competition between invasive and indigenous species: impact of spatial pattern and developmental stage. Plant Ecology 180:153-160

Barrett SCH (1992) Genetics of weed invasions. In: Jain SK, Botsford LW (eds) Applied population biology. Kluwer Academic Publishers, The Netherlands, pp 91-119

Barrett SCH (2003) Mating strategies in flowering plants: the outcrossing-selfing paradigm and beyond. Phil Trans R Soc Lond B 358:991-1004

Barrett SCH, Colautti RI, Eckert CG (2008) Plant reproductive systems and evolution during biological invasion. Mol Ecol 17:373-383

Barthell JF, Randall JM, Thorp RW, Wenner AM (2001) Promotion of seed set in yellow starthistle by honey bees: evidence of an invasive mutualism. Ecol Appl 11:1870-1883

Bartomeus I, Vilà M, Santamaría L (2008) Contrasting effects of invasive plants in plantpollinator networks. Oecologia 155:761-770

Bjerknes A, Totland $\varnothing$, Hegland SJ, Nielsen A (2007) Do alien plant invasions really affect pollination success in native plant species? Biol Conserv 138:1-12

Bossdorf O, Auge H, Lafuma L, Rogers WE, Siemann E, Prati D (2005) Phenotypic and genetic differentiation between native and introduced plant populations. Oecologia 144:1-11

Brandon AL, Gibson DJ, Middleton BA (2004) Mechanisms for dominance in an early successional old field by the invasive non-native Lespedeza cuneata (Dum. Cours.) G. Don. Biol Invasions 6:483-493

Brock JH, Child LE, deWaal LC, Wade M (1995) The invasive nature of Fallopia japonica is enhanced by vegetative regeneration from stem tissues. In: Pyšek P, Prach K, Rejmánek M, Wade M (eds) Plant invasions, general aspects and special problems. SPB Academic Publishing, Amsterdam, pp 131-139

Brown BB, Mitchell RJ (2001) Competition for pollination: effects of pollen of an invasive plant on seed set of a native congener. Oecologia 129:43-49

Brown BB, Mitchell RJ, Graham SA (2002) Competition for pollination between an invasive species (purple loosestrife) and a native congener. Ecol 83:2328-2336

Bruno JF, Fridley JD, Bromberg KD, Bertness MD (2005) Insights into biotic interactions from studies of species invasions. In: Sax DF, Stachowicz JJ, Gaines SD (eds) Species invasions: insights into ecology, evolution, and biogeography. Sinauer Associates, Inc., Sunderland, MA, pp 13-40

Callaway RM, Thelen GC, Rodriguez A, Holben WE (2004) Soil biota and exotic plant invasion. Nat 427:731-733

Carr DE, Dudash MR (2003) Recent approaches into the genetic basis of inbreeding depression in plants. Phil Trans R Soc Lond B 358:1071-1084

Chang SM, Rausher MD (1998) Frequency-dependent pollen discounting contributes to maintenance of a mixed mating system in the common morning glory Ipomoea purpurea. Am Nat 152:671-683

Chittka L, Schürkens S (2001) Successful invasion of a floral market. Nat 411:653 
Clewell AF (1964) The biology of the common native lespedezas in southern Indiana. Brittonia $16: 208-219$

Clewell AF (1966) Natural history, cytology and isolating mechanisms of the native American Lespedezas. Bull Tall Timbers Res Stn 6:10-12

Cole CT, Biesboer DD (1992) Monomorphism, reduced gene flow, and cleistogamy in rare and common species of Lespedeza (Fabaceae). Am J Bot 79:567-575

Colwell RK (2005) EstimateS: Statistical estimation of species richness and shared species from samples. Version 7.5

Cope WA (1966) Cross-pollination in Sericea Lespedeza. Crop Sci 6:469-470

Cox GW (2004) Alien species and evolution. Island Press, Washington, D.C.

D'Antonio CM, Hobbie SE (2005) Plant species effects on ecosystem processes. In: Sax DF, Stachowicz JJ, Gaines SD (eds) Species invasions. Sinauer Associates, Inc., Sunderland, MA, pp 65-84

Daehler CC (1998) Variation in self-fertility and the reproductive advantage of self-fertility for an invading plant (Spartina alterniflora). Evol Ecol 12:553-568

Dalsgaard B, Gonzalez AMM, Olesen JM, Timmermann A, Andersen LH, Ollerton J (2008) Pollination networks and functional specialization: a test using Lesser Antillean planthummingbird assemblages. Oikos 117:789-793

Dlugosch KM, Parker IM (2008) Founding events in species invasions: genetic variation, adaptive evolution, and the role of multiple introductions. Mol Ecol 17:431-449

Donnelly ED (1955) The effects of outcrossing on forage and seed yields in sericea lespedeza, $L$. cuneata. Agron J 47:466-467

Drake JM, Baggenstos P, Lodge DM (2005) Propagule pressure and persistence in experimental populations. Biol Lett - UK 1:480-483

Goodin DG, Fay PA, McHugh MJ (2003) Climate variability in tallgrass prairie at multiple timescales: Konza Prairie Biological Station. In: Greenland D, Goodin DG, Smith RC (eds) Climate variability and ecosystem response at long-term ecological research sites. Oxford University Press, NY, pp 411-424

Great Plains Flora Association (1986) Flora of the great plains. University Press of Kansas, Lawrence, KS

Gross CL (2001) The effect of introduced honeybees on native bee visitation and fruit-set in Dillwynia juniperina (Fabaceae) in a fragmented ecosystem. Biol Conserv 102:89-95

Kandori K, Hirao T, Matsunaga S, Kurosaki T (2009) An invasive dandelion unilaterally reduces the reproduction of a native congener through competition for pollination. Oecologia 159:559-569

Lambrinos JG (2001) The expansion history of a sexual and asexual species of Cortaderia in California, U.S.A. J Ecol 89:88-98

Lambrinos JG (2004) How interactions between ecology and evolution influence contemporary invasion dynamics. Ecol 85:2061-2070

Larson KC, Fowler SP, Walker JC (2002) Lack of pollinators limits fruit set in the exotic Lonicera japonica. Am Midl Nat 148:54-60

Lee CE (2002) Evolutionary genetics of invasive species. Trends Ecol Evol 17:386-391

Leung B, Drake JM, Lodge DM (2004) Predicting invasions: propagule pressure and the gravity of allee effects. Ecol 85:1651-1660

Levin DA (2003) Ecological speciation: lessons from invasive species. Syst Bot 28:643-650

Lloyd DG (1992) Self- and cross-fertilization in plants: the selection of self-fertilization. Int J Plant Sci 153:370-380

McKey DB, Kaufmann SC (1988) Naturalization of exotic Ficus species (Moraceae) in south Florida. Paper presented at Proceedings of the Symposium on Exotic Pest Plants 1988. University of Miami, Florida 
Mitchell RJ, Flanagan RJ, Brown BJ, Waser NM, Karron JD (2009) New frontiers in competition for pollination. Ann Bot 103:1403-1413

Moragues E, Traveset A (2005) Effect of Carpobrotus spp. on the pollination success of native plant species of the Balearic Islands. Biological Conservation 122:611-619

Morales CL, Traveset A (2009) A meta-analysis of impacts of alien vs. native plants on pollinator visitation and reproductive success of co-flowering native plants. Ecol Lett 12:716-728

Muñoz AA, Cavieres LA (2008) The presense of a showy invasive plant disrupts pollinator service and reproductive output in native alpine species only at high densities. J Ecol 96:459-467

Nadel H, Frank JH, R.J. Knight J (1992) Escapees and accomplices: the naturalization of exotic Ficus and their associated faunas in Florida. Florida Entomologist 75:29-38

Nielsen C, Heimes C, Kollmann J (2008) Little evidence for negative effects of an invasive alien plant on pollinator services. Biol Invasions 10:1353 - 1363

Novak SJ, Mack RN, Soltis DE (1991) Genetic variation in Bromus tectorum (Poaceae): population differentiation in its North American range. Am J Bot 78:1150-1161

Ohlenbusch PD, Bidwell T, Fick WH, Scott W, Clubine S, Coffin M (2007) Sericea lespedeza: history, characteristics, and identification. Kansas State University Agricultural Experiment Station and Cooperative Extension Service, Manhattan, KS

Pannell JR, Barrett SCH (1998) Baker's Law revisited: reproductive assurance in a metapopulation. Evol 52:657-668

Pappert RA, Hamrick JL, Donovan LA (2000) Genetic variation in Pueraria lobata (Fabaceae), an introduced, clonal, invasive plant of the southeastern United States. Am J Bot 87:12401245

Parker IM (1997) Pollinator limitation of Cytisus scoparius (scotch broom), an invasive exotic shrub. Ecol 78:1457-1470

Parker IM, Haubensak KA (2002) Comparative pollinator limitation of two non-native shrubs: do mutualisms influence invasions? Oecologia 130:250-258

Parker IM, Rodriguez J, Loik ME (2003) An evolutionary approach to understanding the biology of invasions: local adaptation and general-purpose genotypes in the weed Verbascum thapsus. Conserv Biol 17:59-72

Potts SG (2005) Recording pollinator behaviour on flowers. In: Dafni A, Kevan PG, Husband BC (eds) Practical pollination biology. Enviroquest, Ltd., Cambridge, Ontario, Canada, pp 330-339

Prentis PJ, Wilson JRU, Dormontt EE, Richardson DM, Lowe AJ (2008) Adaptive evolution in invasive species. Trends Plant Sci 13:288-294

Pyšek P, Mandák B, Francírková T, Prach K (2001) Persistence of stout clonal herbs as invaders in the landscape: a field test of historical records. In: Brundu G, Brock J, Camarda I, Child L, Wade M (eds) Plant invasions: species ecology and ecosystem management. Backhuys Publishers, Leiden, pp 235-244

Rejmánek M, Richardson DM, Higgins SI, Pitcairn MJ, Grotkopp E (2005) Ecology of invasive plants: state of the art. In: Mooney HA, Mack RN, McNeely JA, Neville LE, Schei PJ, Waage JK (eds) Invasive alien species: a new synthesis. Vol 63: SCOPE. Island Press, Washington, D.C., pp 104-161

Richardson DM, Allsopp N, D'Antonio CM, Milton SJ, Rejmánek M (2000) Plant invasions -- the role of mutualisms. Biol Rev 75:65-93

Rodger JG, vanKleunen M, Johnson SD (2010) Does specialized pollination impede plant invasions? Int J Plant Sci 171:382-391

Sargent RD, Ackerly DD (2008) Plant-pollinator interactions and the assembly of plant communities. Trends Ecol Evol 23:123-130

SAS Institute Inc. (2002-2003) SAS 9.1 TS Level 1M3, Cary, NC

Schaffer WM, Jensen DB, Hobbs DE, Gurevitch J, Todd JR, Schaffer MV (1979) Competition, foraging energetics and the cost of sociality in three species of bees. Ecol 60:976-987 
Schaffer WM, Zeh DW, Buchmann SL, S.Kleinhans, Schaffer MV, Antrim J (1983) Competition for nectar between introduced honey bees and native North American bees and ants. Ecol 64:564-577

Schutzenhofer MR (2007) The effect of herbivory on the mating system of congeneric native and exotic Lespedeza species. Int J Plant Sci 168:1021-1026

Simberloff D (2006) Invasional meltdown 6 years later: important phenomenon, unfortunate metaphor, or both? Ecol Lett 9:912-919

Simberloff D, VonHolle B (1999) Positive interactions of nonindigenous species: invasional meltdown. Biol Invasions 1:21-32

Stitt RE (1946) Natural crossing and segregation in sericea lespedeza, Lespedeza cuneata (Dumont) G. Don. J Am Soc Agron 38:1-5

Stout JC, Kells AR, Goulson D (2002) Pollination of the invasive exotic shrub Lupinus arboreus (Fabaceae) by introduced bees in Tasmania. Biol Conserv 106:425-434

Stout JC, Parnell JAN, Arroyo J, Crowe TP (2006) Pollination ecology and seed production of Rhododendron ponticum in native and exotic habitats. Biodiversity \& Conservation 15:755-777

Sundberg MI, Slaughter DM, Crupper SS (2002) Application of randomly amplified polymorphic DNA (RAPD) fingerprinting to detect genetic variation in sericea lespedeza (Lespedeza cuneata). T Kans Acad Sci 105:91-95

Takakura K-I, Nishida T, Matsumoto T, Nishida S (2009) Alien dandelion reduces the seed-set of a native congener through frequency-dependent and one-sided effects. Biol Invasions 11:973-981

Thomson D (2005) Measuring the effects of invasive species on the demography of a rare endemic plant. Biological Invasions 7:615-624

Totland $\varnothing$, Nielsen A, Bjerknes A, Ohlson M (2006) Effects of an exotic plant and habitat disturbance on pollinator visitation and reproduction in a boreal forest herb. Am J Bot 93:868-873

Traveset A, Richardson DM (2006) Biological invasions as disruptors of plant reproductive mutualisms. Trends Ecol Evol 21:208-216

Valdovinos FS, Ramos-Jiliberto R, Flores JD, Espinoza C, Lopez G (2009) Structure and dynamics of pollination networks: the role of alien plants. Oikos 118:1190-1200

Watson MA, Casper BB (1984) Morphogenetic constraints on patterns of carbon distribution in plants. Annu Rev Ecol Syst 15:233-258

Wilson JRU, Dormontt EE, Prentis PJ, Lowe AJ, Richardson DM (2009) Something in the way you move: dispersal pathways affect invasion success. Trends Ecol Evol 24:136-144

Woods TM (2006) A comparison of the reproductive systems of the invasive Lespedeza cuneata (Dum.-Cours.) G. Don (Fabaceae) with three native congeners in the Flint Hills region of the tallgrass prairie. M.S. Thesis, Kansas State University

Woods TM, Hartnett DC, Ferguson CJ (2009) High propagule production and reproductive fitness homeostasis contribute to the invasiveness of Lespedeza cuneata (Fabaceae). Biol Invasions 11:1913-1927 